\title{
Perancangan dan Analisis Kekuatan Frame Sepeda Lipat Menggunakan Autodesk Inventor
}

\author{
(Design and Strength Analysis of Folding Bicycle Frame Using Autodesk Inventor) \\ Berli Paripurna Kamiel ${ }^{a}$, Ghozi Adib Nugraha ${ }^{b}$, Sunardi $^{c}$ \\ ${ }^{\mathrm{a}, \mathrm{b}, \mathrm{c}}$ Program Studi Teknik Mesin, Fakultas Teknik, Universitas Muhammadiyah Yogyakarta \\ Jalan Brawijaya, Tamantirto, Kasihan, Bantul, Di Yogyakarta, 55183, Indonesia \\ e-mail: berlikamiel@umy.ac.ida ${ }^{a}$ ghoziadib@gmail.com ${ }^{b}$, sunardi@umy.ac.id ${ }^{c}$
}

\begin{abstract}
Kemacetan Ialulintas adalah masalah yang banyak terjadi di kota-kota besar. Salah satu cara mengatasinya adalah dengan menggunakan transportasi umum. Meskipun demikian, lokasi halte pemberhentian kadang terlalu jauh dari pusat aktivitas masyarakat jika ditembuh dengan berjalan kaki. Hal ini menyebabkan banyak orang tidak tertarik menggunakan transportasi umum. Untuk mengatasi masalah ini, dibutuhkan alat transportasi individu yang dapat mempermudah mencapai lokasi halte dengan cepat dan aman sehingga penggunaan transportasi umum menjadi menyenangkan. Tujuan perancangan adalah menghasilkan perancangan sepeda lipat yang lebih efisien dari segi ukuran, bobot, dan harga beli dibandingkan sepeda lipat yang sudah ada di pasar. Perancangan dilakukan dengan menggunakan Autodesk Inventor Professional dan dititikberatkan pada frame sepeda. Untuk menjamin kekuatan dan keamanan ketika digunakan, kekuatan frame dihitung dan dianalisis menggunakan metode elemen hingga. Material frame yang dipilih dari hasil perancangan adalah alumunium 6061-T6. Perancangan menghasilkan sepeda lipat dengan dimensi kondisi terlipat adalah $765 \times 742 \times 328 \mathrm{~mm}$. Analisis kekuatan frame memberikan tegangan von mises maksimum sebesar 96,32 $\mathrm{MPa}$, displacement maksimum sebesar $6,925 \mathrm{~mm}$, dan faktor keamanan minimum sebesar 2,8. Angka-angka hasil analisis kekuatan tersebut adalah angka tertinggi dari keseluruhan angka hasil perhitungan. Hal ini disebabkan oleh konsentrasi tegangan pada frame yang mengalami diskontinuitas geometri. Meskipun demikian, semua angka tersebut masih berada pada interval yang aman ditinjau dari tegangan ijin rencana.
\end{abstract}

Abstrak

Kata kunci: sepeda lipat, analisis kekuatan, perancangan, faktor kemanan, Autodesk Inventor

\section{Abstract}

Traffic congestion is one of many problems that occur in big cities. One of the solution to reduce it is by starting to use the public transport, such as bus and train. But, to reach the public transport, some walk is needed and sometimes the distance is too far to go on foot. Other than that, it's often that the public tranport doesn't drop passanger right on the destination, so there will be another walk needed. For that reason, many people don't like to use the public transport. To solve this problem, there should be an individual transportation device that can make commuting using the public transportation mode become less tiring. This design process aims to result a folding bicycle design which is more efficient in size, weight, and cost compared to the exsisting folding bicycles on the market. The design was made using Autodesk Inventor Professional 2015 software. The design was focused on the bicycle frame. To acknowledge the design safety, strength analysis was conducted on Autodesk Inventor Professional 2015 software using the finite element metode. The choosen material for the design was Aluminium 6061-T6. The design process resulted a folding bicycle design with a folded dimention of $765 \times 742 \times 328 \mathrm{~mm}$. From the strength analysis conducted, the design experienced maximum von mises stress of 96,32 MPa, maximum displacement of $6,925 \mathrm{~mm}$, and had minimum safety factor of 2,8. These values were the worst results from the entire design's analysis results and only happened in one area. It happened because there was an acumulated stress 
on some part caused by geometry discontinuity. Even so, the value of the safety factor on this area was still far from the design's allowed stress. In conclusion, the design was safe to use.

Keywords: folding bicycle; strength analysis, design; safety factor; Autodesk Inventor

\section{Pendahuluan}

Kemacetan lalu lintas sudah menjadi hal yang biasa bagi masyarakat perkotaan. Akan tetapi, jika tidak segera ditanggulangi lambat laun akan menjadi masalah yang lebih serius. Penyebab utama kemacetan adalah banyaknya jumlah kendaraan. Sebenarnya, jumlah kendaraan di jalan raya saat ini masih dapat dikurangi dengan beralih memakai kendaraan umum seperti bus atau kereta. Akan tetapi, untuk menuju tempat pemberhentian kendaraan umum diperlukan jarak yang terkadang cukup jauh untuk ditempuh dengan berjalan kaki. Selain itu, kendaraan umum sering tidak berhenti tepat di tempat tujuan, sehingga harus dilanjutkan dengan berjalan kaki. Hal ini membuat masyarakat enggan memakai kendaraan umum.

Untuk itu, diperlukan alat transportasi individual yang dapat memudahkan perjalanan dengan kendaraan umum. Alat tersebut harus memiliki desain yang mudah digunakan, dapat dilipat, ringan, dan ekonomis [1]. Banyak kendaraan yang dapat digunakan untuk transportasi jarak dekat, seperti sepatu roda, skate board, otopet, dan sepeda. Setiap kendaraan memiliki kelebihan dan kekurangan sebagai alat transportasi individual yang memenuhi kriteria tersebut.

Sepatu roda dan skate board memiliki bobot yang ringan dan membutuhkan tempat yang sedikit, tetapi cenderung sulit digunakan kebanyakan orang, terutama karena butuh keseimbangan yang baik dan metode pengereman yang sulit. Dibanding itu, otopet lebih mudah digunakan, tetapi harus dipakai dalam posisi berdiri dan digerakkan dengan menghentakan kaki ke tanah. Ditambah dengan ukuran roda yang kecil, hal itu membuat otopet melelahkan untuk dipakai, terutama di rute yang jauh dan datar. Dibanding otopet, sepeda lebih nyaman digunakan karena memiliki tempat duduk dan digerakkan dengan cara mengayuh pedal sehingga kaki dapat bergerak dalam ritme. Selain itu, sepeda juga cenderung lebih mudah digunakan, memiliki metode pengereman yang sederhana, dan dapat melaju dengan kecepatan yang paling tinggi dibanding sepatu roda, skate board, atau otopet. Akan tetapi, sepeda konvensional tidak memungkinkan untuk dibawa ke dalam kendaraan umum karena ruang yang terbatas. Oleh karena itu, sepeda yang memenuhi kriteria adalah sepeda lipat [2] walaupun dari segi bobot tidak lebih ringan dari sepatu roda, skate board, atau otopet.

Sudah banyak sepeda lipat yang beredar di pasaran sekarang. Namun, desainnya masih dapat dikembangkan. Sebagai contoh, ukuran yang masih kurang ringkas untuk dibawa dalam kendaraan umum dan cara melipat yang masih tidak praktis. Banyak desain sepeda lipat yang ditujukan untuk muat ke dalam bagasi mobil sehingga masih lebih besar dan merepotkan jika dibawa ke dalam kendaraan umum. Jika ada yang sudah mengatasi dua masalah itu, biasanya harganya menjadi mahal. Oleh karena itu, perancangan ini bertujuan menghasilkan desain yang lebih efisien dalam ukuran, bobot, dan biaya sehingga dapat menarik minat masyarakat untuk beralih menggunakan kendaraan umum.

\section{Metode}

Sepeda atau bicycle adalah kendaraan beroda dua yang menggunakan pedal sebagai penggeraknya. Istilah bicycle mulai dipakai pada tahun 1860-an di Perancis dan sejak saat itu digunakan di Perancis dan Inggris untuk mengacu pada kendaraan beroda dua yang digerakkan dengan pedal walaupun dalam perkembangannya sepeda tidak selalu beroda dua [3]. Kehadiran sepeda menggeser pemakaian kuda karena lebih praktis perawatannya dan lebih mudah dikendalikan.

Banyak desain sepeda yang dikembangkan sebelum menjadi desain sepeda yang umum digunakan sekarang ini, salah satunya sepeda lipat. Sesuai dengan namanya, sepeda lipat adalah sepeda yang memiliki keunikan, yaitu dapat dilipat. Sepeda lipat diminati 
karena keringkasannya yang dapat menghemat tempat untuk menyimpannya. Sepeda lipat banyak diminati oleh orang-orang yang tinggal di apartemen atau rumah yang kecil.

Perancangan sepeda lipat akan dilakukan menggunakan software Autodesk Inventor Professional 2015. Terdapat beberapa tahapan dalam mendapatkan rancangan sepeda lipat, seperti yang ditunjukkan pada Gambar 2.1. Pertama, dilakukan studi literatur untuk mendapatkan ide dan teori yang mendasari perancangan. Langkah selanjutnya adalah membuat desain, mulai dari sketsa manual, sketsa 2D, model 3D, hingga assembly. Selanjutnya, dilakukan pemilihan material desain, pemberian beban, dan analisis tegangan desain. Secara sederhana, tahapan ini dapat dilihat dalam diagram pada Gambar 2.2.

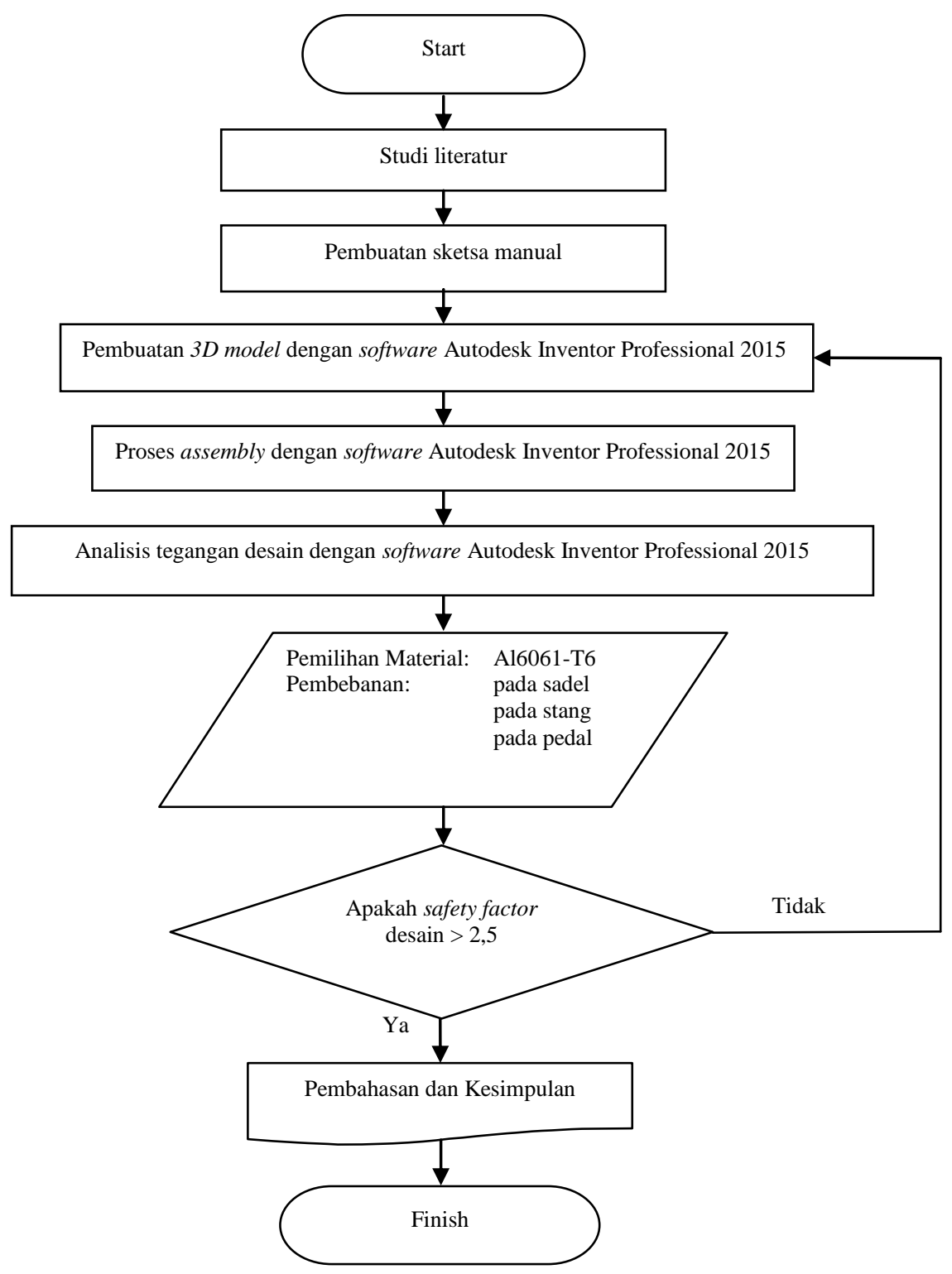

Gambar 2.1 Diagram alir perancangan sepeda lipat 


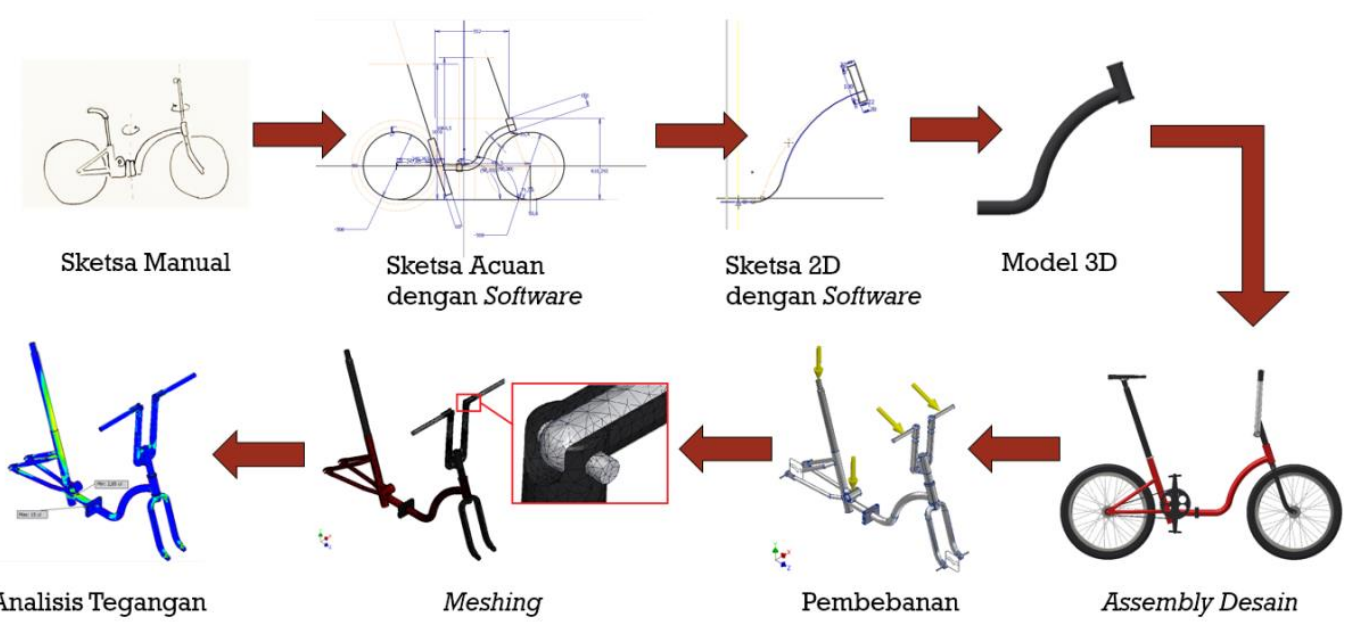

Gambar 2.2 Diagram proses perancangan sepeda lipat

Sketsa manual dibuat dengan sederhana di atas kertas. Hal yang terpenting adalah menggambarkan sebanyak mungkin konsep bentuk, prinsip kerja, fitur-fitur utama desain yang lebih unggul dari sepeda-sepeda yang ada di pasaran [4]. Setelah didapatkan desain yang sesuai, dibuat sketsa yang lebih rinci sebagai acuan desain nantinya. Agar lebih mudah diatur dan rapi, sketsa acuan dibuat menggunakan software Autodesk Inventor Professional 2015. Untuk menghasilkan sebuah desain 3D, perlu dibuat sketsa 2D berdasarkan ukuran yang telah digambarkan pada sketsa acuan. Setelah itu, masingmasing sketsa 2D yang sudah dibuat kemudian diubah menjadi model 3D, dirakit dengan proses yang disebut assembly, dan menjadi desain 3D yang diinginkan.

Untuk mengetahui kekuatan desain yang dihasilkan, dilakukan analisis tegangan dengan software Autodesk Inventor Professional 2015. Analisis tegangan dimulai dengan melakukan pembebanan, pemilihan material, meshing, kemudian melakukan analisis. Pembebanan diberikan pada bagian seat, bottom bracket, dan stang. Pembebanan pada seat dan stang diberikan karena bagian tersebut merupakan tumpuan utama dari bobot pengguna saat menaiki sepeda [5]. Di sisi lain, pembebanan pada bottom bracket diberikan karena gaya yang terjadi pada pedal akan mempengaruhi tegangan yang dialami oleh frame [6]. Material yang dipilih untuk desain adalah aluminium 6061-T6 karena memiliki properties yang baik dengan harga yang murah dan mudah diproses [7]. Analisis akan menghasilkan hasil berupa gambar dengan gradien warna dan angka yang menunjukkan nilai von mises stress, displacement, dan safety factor.

\section{Hasil dan Pembahasan}

\subsection{Hasil perancangan}

Perancangan sepeda lipat menghasilkan satu desain akhir. Desain akhir menggunakan frame lengkung berbahan AL6061-T6 dengan satu engsel di bagian tengahnya, seperti yang dapat dilihat pada Gambar 3.1. Sepeda didesain untuk penggunaan dengan postur tegak, karena postur tegak meminimalisasi kelelahan otot pengguna [8]. Frame lengkung memiliki beberapa kelebihan, seperti menghemat tempat dan lebih mudah digunakan oleh pengendara wanita. Ukuran roda yang dipilih dalam desain adalah roda $20 \mathrm{inci}$, ukuran yang umum untuk sepeda lipat, karena roda yang terlalu kecil akan memberikan banyak kekurangan, seperti dalam kenyamanan berkendara dan grip roda pada jalanan yang buruk [9]. 


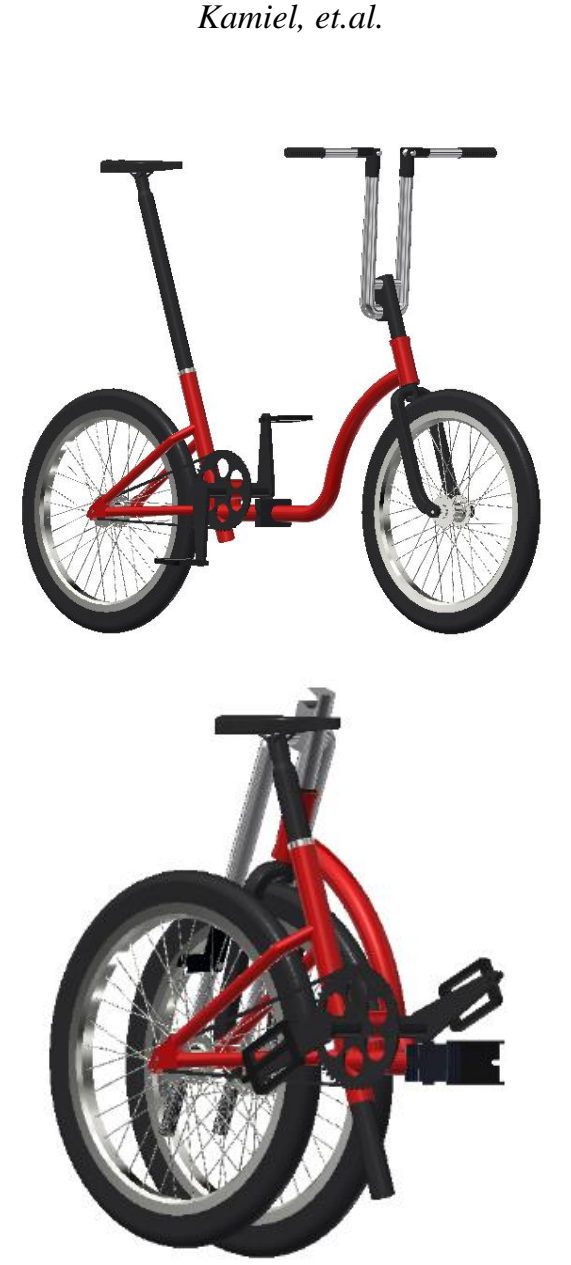

Gambar 3.1 Sepeda lipat hasil perancangan

Dimensi dasar sepeda lipat hasil perancangan dapat dilihat pada gambar 3.2 dan 3.3 . Pada kondisi terbuka maksimal, sepeda memiliki panjang top tube efektif sebesar 727,93 $\mathrm{mm}$ dan ketinggian maksimum seat adalah $973,13 \mathrm{~mm}$ sehingga masih nyaman dikendarai orang-orang berpostur tinggi, sekitar $190 \mathrm{~cm}$. Tinggi bottom bracket adalah 296,49 mm dan ground clearence sebesar $138,86 \mathrm{~mm}$, tergantung crank set yang digunakan untuk menghindari kaki yang bersentuhan dengan tanah saat mengayuh pedal. Sepeda juga memiliki wheelbase sebesar $992,81 \mathrm{~mm}$, kurang lebih seperti sepeda yang terdapat di pasaran untuk menjaga kenyamanan berkendara tetap sama [10]. Ketika terlipat, dimensi sepeda dapat berkurang menjadi $764,94 \times 741,53 \times 321,5 \mathrm{~mm}$. Ukuran ini lebih kecil dari sepeda lipat Phoenix yang juga memakai roda 20 inci.

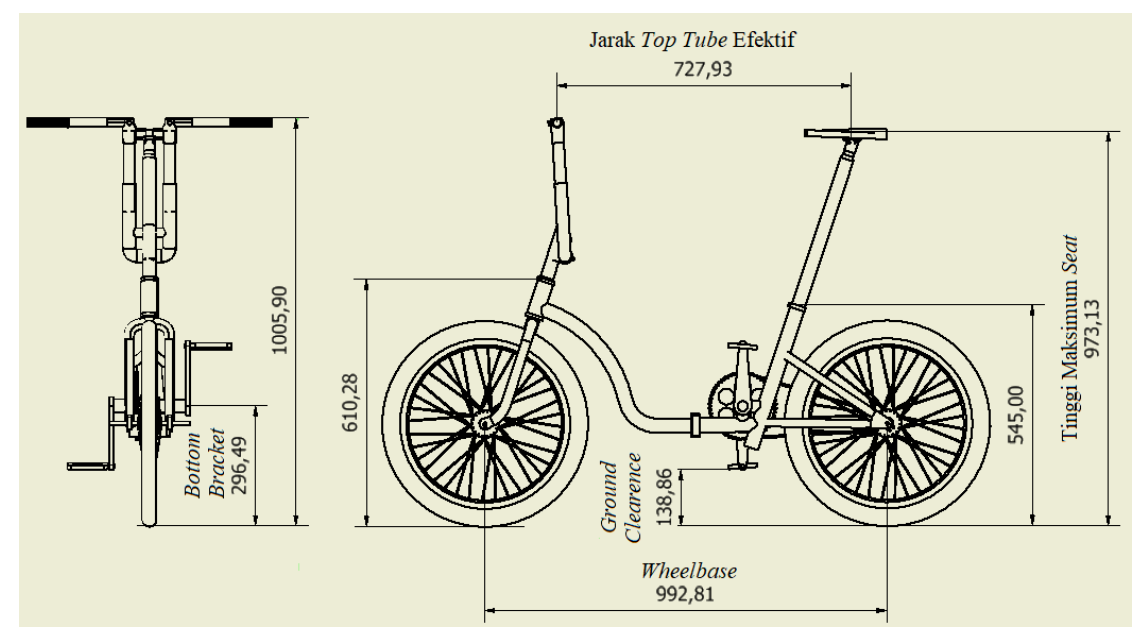

Gambar 3.2 Dimensi sepeda pada kondisi terbuka 

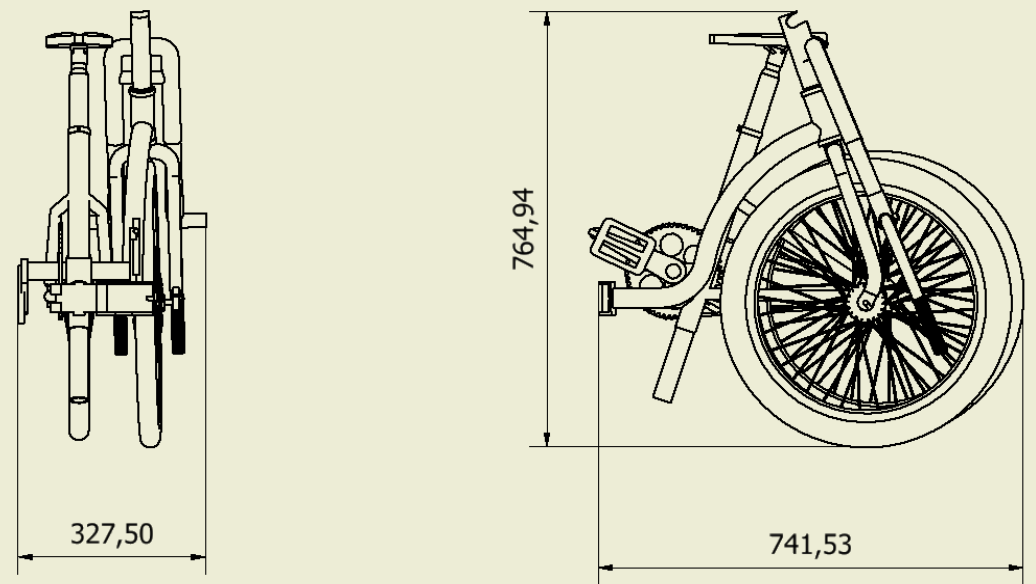

Gambar 3.3 Dimensi sepeda pada kondisi terlipat

\subsection{Analisis tegangan}

Untuk mengetahui kekuatan desain, dilakukan analisis tegangan dengan software Autodesk Inventor Professional 2015. Tegangan yang dianalisis merupakan tegangan yang dihasilkan dari pembebanan statis. Sambungan yang ada pada model dianggap sebagai sambungan yang rigid. Proses dan hasil dari analisis tegangan yang dilakukan adalah sebagai berikut:

\subsubsection{Von mises stress}

Von mises stress adalah tegangan yang nilainya didapat dari teori kegagalan karena energi distorsi. Jika nilai von mises stress melebihi tegangan luluh dari material, desain akan mengalami kegagalan [11]. Pada simulasi tegangan, nilai von mises stress dapat dilihat dari warnanya, seperti yang dapat dilihat pada Gambar 3.4. Dari simulasi yang dilakukan, nilai von mises stress maksimum yang terjadi pada kondisi terbeban adalah 96,32 MPa. Nilai tersebut hanya terjadi di beberapa titik dan tidak melampaui nilai tegangan luluh AL6061-T6 sebesar $276 \mathrm{MPa}$ [12]. Sebagian besar, hasil analisis tegangan pada desain masih berwarna biru. Artinya, sebagian besar tegangan yang terjadi pada desain hanya sekitar 16,07 MPa, masih sangat jauh di bawah tegangan luluh AL6061-T6. Oleh karena itu, tegangan yang terjadi masih masuk dalam batas yang aman.

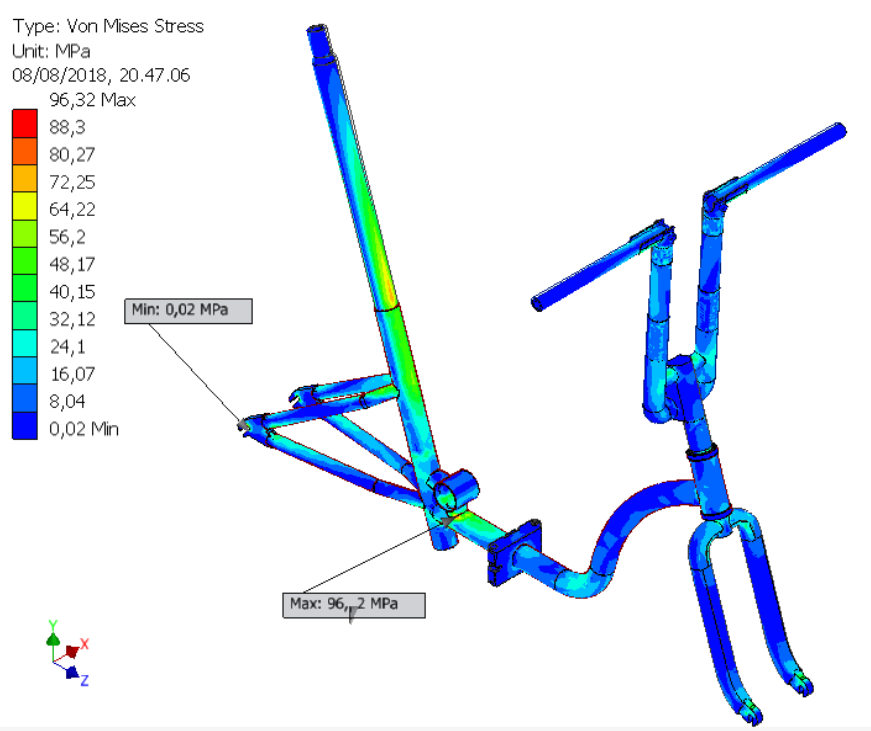

Gambar 3.4 Hasil analisis von mises stress desain sepeda lipat 


\subsubsection{Displacement}

Displacement menunjukkan perubahan bentuk dari desain setelah dilakukan pembebanan. Pada simulasi tegangan, nilai displacement yang terjadi dapat dilihat dari warnanya, seperti yang dapat dilihat pada Gambar 3.5. Dari simulasi yang dilakukan, nilai displacement maksimum yang terjadi pada kondisi terbeban adalah $6,925 \mathrm{~mm}$. Displacement ini terjadi pada tegangan maksimal $96,32 \mathrm{MPa}$, masih jauh di bawah tegangan luluh AL6061-T6 sebesar $276 \mathrm{MPa}$. Artinya, displacement masih berada pada daerah elastis. Dengan nilai yang cukup kecil, displacement ini masih dapat diterima.

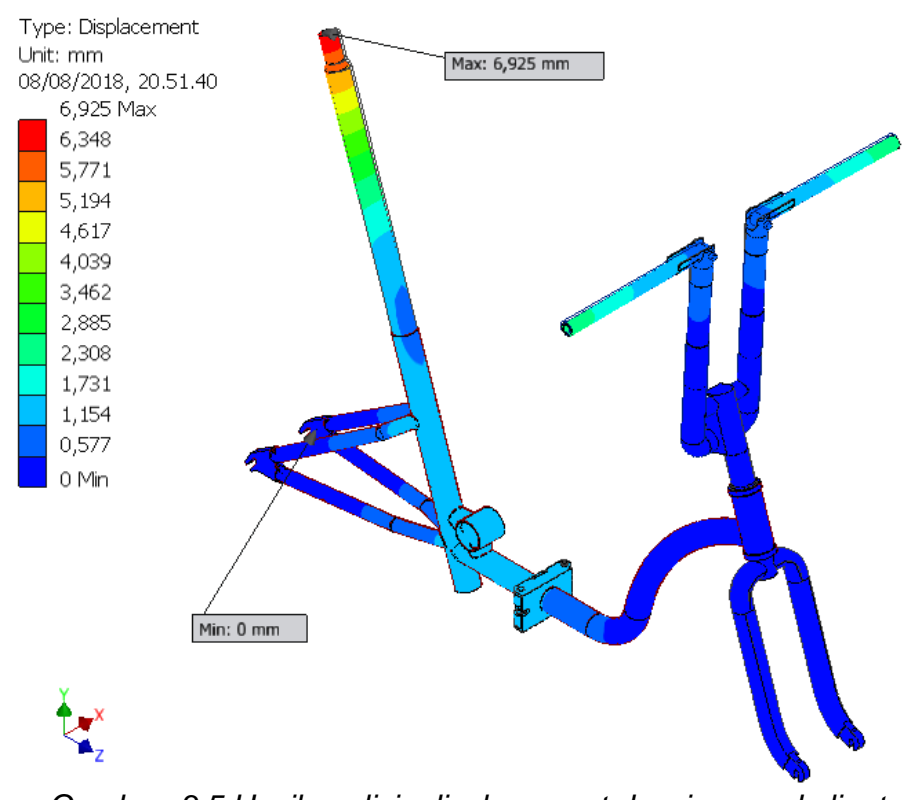

Gambar 3.5 Hasil analisis displacement desain sepeda lipat

\subsubsection{Safety factor}

Safety factor atau faktor keamanan yang didapat dari hasil analisis adalah sebesar 2,85 sampai 15. Artinya, bagian paling lemah pada desain mampu mengatasi 2,85 kali beban yang diijinkan yaitu $100 \mathrm{~kg}$. Meskipun demikian, seperti yang dapat dilihat pada Gambar 3.6, mayoritas bagian sepeda berwarna biru. Artinya, sebagian besar bagian sepeda memiliki safety factor di atas beban yang diijinkan.

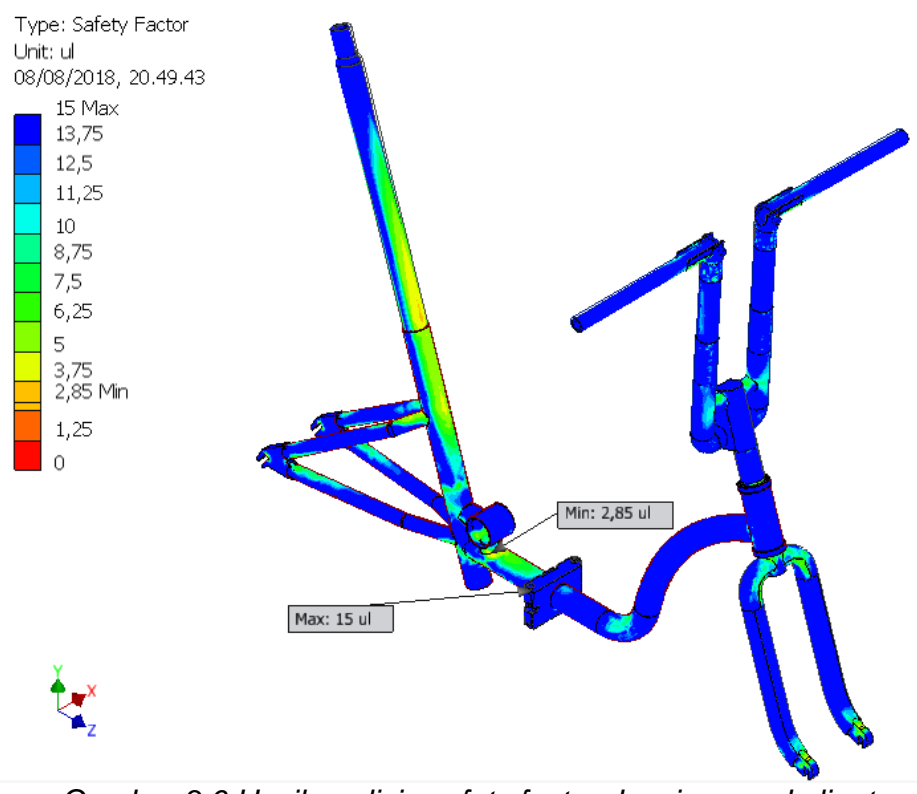

Gambar 3.6 Hasil analisis safety factor desain sepeda lipat 


\subsubsection{Analisis tegangan pada frame belakang}

Dari hasil analisis, desain masih didominasi warna biru dan hijau, seperti yang terlihat pada Gambar 3.7 dan 3.8. Namun, terdapat titik dengan warna mendekati merah. Hal ini menunjukkan sebagian besar tegangan yang dialami oleh desain masih di bawah tegangan ijinnya, tetapi terdapat titik dengan tegangan yang besar. Penyebab terkumpulnya tegangan di titik tersebut adalah posisi titik yang tepat di bawah bottom bracket yang merupakan salah satu titik pembebanan dan diskontinuitas geometri pada sambungan. Diskontinuitas geometri pada sambungan dapat diatasi dengan pengelasan yang bagus. Akan tetapi, safety factor terendah pada titik tersebut masih berada pada warna jinga, dengan nilai 2,85. Artinya, desain frame belakang masih aman untuk dipakai.

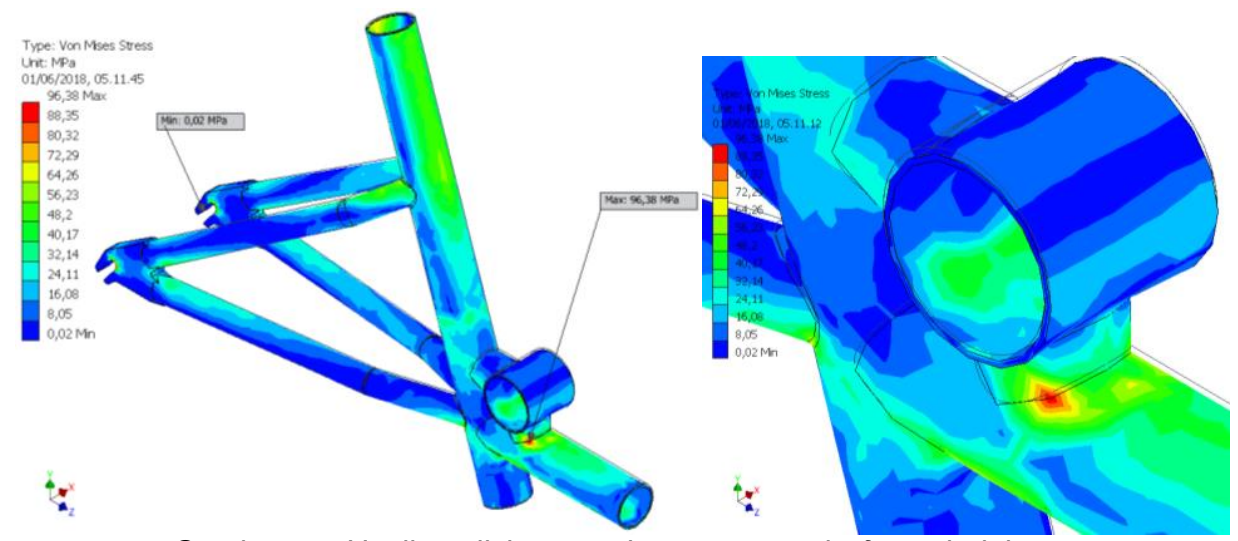

Gambar 3.7 Hasil analisis von mises stress pada frame belakang
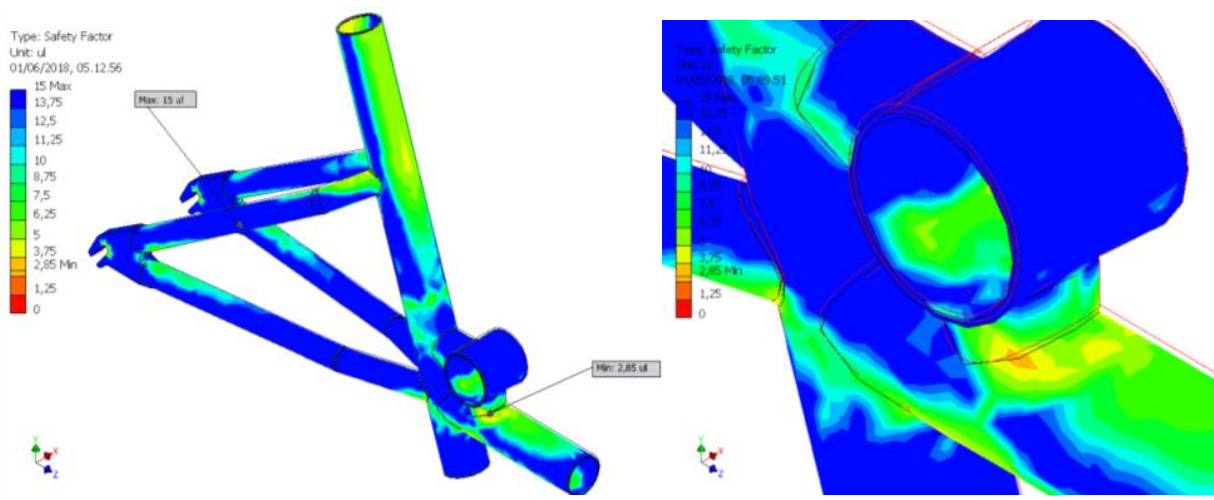

Gambar 3.8 Hasil analisis safety factor pada frame belakang

\subsection{Perbandingan desain sepeda lipat}

Sepeda lipat yang ada di pasaran memiliki bentuk yang beragam. Hal ini untuk mendapatkan nilai lebih bagi sepeda lipat tersebut dibanding produk pesaingnya. Beberapa hal yang dapat menjadi nilai lebih dari desain sepeda lipat adalah bobot, jumlah tahapan pelipatan, dan dimensi sepeda ketika terlipat. Perbandingan kelebihan sepeda hasil rancangan dengan sepeda-sepeda yang ada di pasaran dapat dilihat pada Tabel 3.1.

\begin{tabular}{llccc}
\multicolumn{5}{c}{ Tabel 3.1 Perbandingan desain sepeda lipat } \\
\hline $\mathbf{N}$ & \multicolumn{1}{c}{ Nama Produk } & $\begin{array}{c}\text { Bobot } \\
\mathbf{( k g )}\end{array}$ & $\begin{array}{c}\text { Jumlah Tahapan } \\
\text { Pelipatan }\end{array}$ & $\begin{array}{c}\text { Dimensi Sepeda Saat } \\
\text { Terlipat (mm) }\end{array}$ \\
$\mathbf{0}$ & & 12,5 & 3 & $765 \times 742 \times 328$ \\
\hline $\mathbf{1}$ & Sepeda Hasil Perancangan & 15 & 3 & $844 \times 709 \times 350$ \\
\hline $\mathbf{2}$ & Phoenix & 14 & 3 & $750 \times 650 \times 350$ \\
\hline $\mathbf{3}$ & Polygon Urbano 3 & 10,9 & 5 & $1130 \times 290 \times 580$ \\
\hline $\mathbf{4}$ & Strida LT & 6,9 & 3 & $840 \times 550 \times 200$ \\
\hline $\mathbf{5}$ & Hummingbird & 10,3 & 4 & $585 \times 565 \times 270$ \\
\hline $\mathbf{6}$ & Brompton & & & \\
\hline
\end{tabular}


Dari Tabel 3.1, sepeda lipat hasil perancangan memiliki beberapa kelebihan. Bobot sepeda lipat hasil perancangan lebih ringan dibanding sepeda lipat merk Poenix dan Polygon Urbano 3. Dimensi sepeda lipat hasil perancangan lebih kecil dari sepeda lipat merk Phoenix.

\section{Kesimpulan} berikut:

Dari hasil perancangan dan analisis sepeda lipat, dapat diambil kesimpulan sebagai

a. Sepeda lipat hasil perancangan menggunakan komponen-komponen sebagai berikut:

1. Frame depan menggunakan AL6061-T6 tube OD $35 \mathrm{~mm}$, ID $33 \mathrm{~mm}$

2. Frame belakang menggunakan AL6061-T6 tube OD $35 \mathrm{~mm}$, ID $32 \mathrm{~mm}$

3. Engsel menggunakan AL6061-T6 $98 \times 58 \mathrm{~mm}$

4. Seat bar menggunakan hi-ten steel $600 \mathrm{~mm}$, OD $33 \mathrm{~mm}$, ID $27 \mathrm{~mm}$

5. Stang menggunakan AL6061-T6 tube $255 \times 620 \mathrm{~mm}$

6. Fork menggunakan hi-ten steel dengan slot roda $270 \times 100 \mathrm{~mm}$

7. Bearing menggunakan bearing BB30

8. Rantai menggunakan rantai United R-101

9. Crank set menggunakan crank set single speed 36T

10. Pedal menggunakan pedal lipat aluminium-plastik

11. Free wheel menggunakan free wheel United 14T

12. Roda menggunakan Roda 20 inci

b. Sepeda lipat hasil perancangan memiliki bobot seberat $12,5 \mathrm{~kg}$, tahapan pelipatan sebanyak 3 tahap, dan dimensi terlipat sebesar $765 \times 742 \times 328 \mathrm{~mm}$. Bobot sepeda hasil perancangan lebih ringan dibanding sepeda lipat merk Phoenix dan Polygon Urbano 3 dengan berat $15 \mathrm{~kg}$ dan $14 \mathrm{~kg}$. Dimensi sepeda lipat hasil perancangan lebih kecil dari sepeda lipat merk Phoenix yang terlipat dengan dimensi $844 \times 709 \times 350 \mathrm{~mm}$.

c. Berdasarkan perancangan yang dilakukan, safety factor sepeda adalah 2,85 . Nilai itu adalah nilai terendah dari keseluruhan desain dan hanya terjadi pada 1 titik. Nilai safety factor rendah lainnya adalah sekitar 3,3 dan selebihnya memiliki nilai di atas itu. Hal ini terjadi karena tegangan terkumpul akibat diskontinuitas geometri pada beberapa bagian. Meskipun demikian, nilai safety factor pada titik terkumpulnya tegangan masih jauh di atas tegangan ijin desain sehingga dapat disimpulkan bahwa desain aman untuk digunakan.

\section{Daftar Pustaka}

[1] Hossain MK, Chowdhury MMR, Black M, Elmore C, Thomas W, Ray KP, editors. Design of a Portable Assisted Mobility Device-A Sustainable Urban Transport. International Conference on Conected Vehicles and Expo; 2013; United State of America: Tuskegee University.

[2] Maleque MA, Hossain S, Dyuti S. Material Properties and Design Aspects of Folding Bicycle Frame. Advanced Material Research. 2011.

[3] Herhily DV. Bicycle: the History. United States of America: Quebecor World; 2007.

[4] Muthiah A, Prakash A, Ramadass R. Foldable Bicycle: Evaluation of Existing Design nd Novel Design Proposals. ARPN Journal of Engineering and Applied Science. 2014;9(5):706-10.

[5] Hatwar AM, Bargat SP, Bohra BA. Design of Single Fork of Folding Bicycle. International Journal of Modern Engineering Research. 2016;6(5):64-70.

[6] Manolova AV, Crequy S, Lestriez P, Debraux P, Bertucci WM. Relationship between the Pedaling Biomechanics and Strain of Bicycle Frame during Submaximal Tests. Sports. 2015;3:87-102; doi:10.3390/sports3020087.

[7] Rontescu C, Cicic DT, Amza CG, Dobrota D. Choosing The Optimum Material For Making A Bicycle Frame. METABK. 2015;54(4):679-82.

[8] Balasubramanian V, Jagannath M, Adalarasu K. Muscle Fatigue Based Evaluation of Bicycle Design. Applied Ergonomic. 2014;45:339-45.

[9] Hadland T, Lessing H-E. Bicycle Design: An llustrated History. United State of America: MIT Press; 2014. 
[10] Shisir S, Manjunath P, Pavanasudan R, Sathyajith R. Design and Fabrication of Foldable Bicycle. SSRG International Journal of Mechanical Engineering. 2015;2(6):612.

[11] Popov EP. Mekanika Teknik. Jakarta: Erlangga; 1984.

[12] Committee AH. Properties and Selection: Nonferrous Alloys and Special-Purpose Materials. ASM Handbook. 2: ASM International; 1990. p. 62-122. 